\title{
Issues Faced by Minority Ethnic Groups' Students Reflected in Their Writing
}

\author{
Triastama Wiraatmaja ${ }^{\mathrm{a}, 1^{*} \text {, }}$ \\ a Universitas Muhammadiyah Malang, Jalan Raya Tlogomas 256, Malang, Indonesia, 65144 \\ 1 triastama@umm.ac.id \\ ${ }^{*}$ Corresponding Author
}

\begin{tabular}{l}
\hline INFO ARTIKEL \\
\hline Sejarah Artikel: \\
Diterima: 8 Maret 2020 \\
Direvisi: 9 Maret 2020 \\
Disetujui: 18 Maret 2020 \\
Tersedia Daring: 12 April \\
2020 \\
\hline Kata Kunci: \\
Kelompok etnis minoritas \\
Kosakata \\
Voyant tools \\
Writing
\end{tabular}

ABSTRAK

Penelitian ini bertujuan menelaah permasalahan yang dihadapi mahasiswa dari kelompok etnis minoritas jurusan pendidikan bahasa Inggris di universitas swasta di Malang, dan apakah etnisitas dan aspek sosial memiliki pengaruh terhadap kemampuan bahasa mahasiswa, sebagaimana terlihat dari kosakata mereka di kelas writing. Peneliti menelaah tulisan dari 16 mahasiswa dari etnis mayoritas dan minoritas yang kemudian di analisis dengan Voyant Tools yang menekankan pada kepadatan kosakata dan rata-rata kata per kalimat. Dilanjutkan dengan menyebarkan kuesioner ke delapan mahasiswa dari kelompok etnis minoritas, dan dua mahasiswa yang meraih angka tertinggi berdasarkan Voyant Tools terpilih untuk mengikuti sesi interview. Sesi tersebut dianalisis dengan Thick Description berfokus pada isu terkait kecakapan kosakata dan etnisitas. Hasil yang diperoleh dari Voyant Tools menunjukkan mahasiswa dari kelompok etnis minoritas tidak lebih baik dibandingkan mahasiswa dari kelompok etnis mayoritas. Hasil tersebut merupakan gambaran dari kecakapan kosakata mereka dikelas writing, dan hasil tersebut dipengaruhi beberapa hambatan seperti kurangnya fasilitas pendidikan di daerah asal mereka, dan pelecehan verbal yang mengarah pada etnisitas mereka. Peneliti juga menemukan pelecehan secara verbal terkait etnisitas mereka, dimana pelecehan tersebut masuk dalam konteks diskriminasi individu yang memperkuat pemikiran bahwa mahasiswa etnis mayoritas menggunakan diskriminasi sebagai alat untuk menunjukkan perasaan superior terhadap kelompok inferior. Masyarakat cenderung tidak menghiraukan fakta bahwa pelecehan verbal antar mahasiswa, terjadi di lingkungan universitas dan secara tidak langsung mempengaruhi performa mahasiswa. Paparan ini didukung hasil yang didapat dari Voyant Tools dimana mahasiswa dari kelompok etnis minoritas tidak lebih baik dari kelompok mayoritas, dan efeknya tampak dari kemampuan writing mereka, terutama dalam kecakapan kosakata.

\begin{tabular}{l}
\hline Keywords: \\
Minority ethnic groups \\
Voyant tools \\
Vocabulary \\
Writing
\end{tabular}

\section{ABSTRACT}

This research attempted to determine issues faced by minority ethnic groups' students in English Language Education Department in private university in Malang, and whether ethnicity and social aspects played significant roles in the students' language proficiency reflected in their vocabulary in writing class. The researcher analysed writing samples taken from 16 students from both minority and majority ethnic groups by utilising Voyant Tools which focused on vocabulary density and average words per sentence. Followed with spreading questionnaires to eight students of minority ethnic groups and interviewing two of them who earned highest scored based on Voyant Tools. Those sessions were analysed with Thick Description to focus on related issues regarding vocabulary proficiency and ethnicities. The results taken from Voyant Tools indicated that students from minority ethnic groups were lesser than the students from majority one's. Those results depicted the vocabulary proficiency of students from minority ethnic groups in writing, and 
those results were affected by educational deprived in their origins, and verbal abuse regarding their ethnicity. The researcher discovered that verbal abuse towards ethnicity regarded as individual discrimination that strengthens the majority's idea to emphasise their superiority over the inferior. People tend to overlook the fact that verbal abuse among students was existed in universities and it affecting students' performance. This notion was supported by the result taken from Voyant Tools in which the result shown that the minority ethnic groups were lesser than majority one's and the effect were reflected at their writing, notably their vocabulary proficiency.

(C) 2020, Triastama Wiraatmaja This is an open access article under CC-BY license

How to Cite: Wiraatmaja, T. (2020). Issues Faced by Minority Ethnic Groups' Students Reflected in Their Writing. JURNAL SATWIKA, 4 (1), 22-33 doi:

https://doi/org/10.22219/SATWIKA.Vol4.No1.22-33

\section{Introduction}

Many proclaimed that Indonesia has been entering a new era of industrial revolution of the so-called 4.0. Ironically, Indonesia that geographically consist of more than 13000 islands, still suffer of education inequality, notably for those who live in remote areas all over Indonesian's archipelago. The lacks of infrastructures and quality of education in some remote areas in Indonesia, as one of the developing countries, have emerged to be the obstacles to ensure equal opportunity of education for all of its citizens. As Cali CoLab Workshop (2018) elaborated below,

"Educational infrastructure in most countries around the world is underfunded and overextended, and schools are more vulnerable to natural hazards than other building types1, not only putting children at significant risk, but also reducing the quality of education and limiting opportunities for economic and social growth and other community benefits."

Unsurprisingly, in order to obtain better education, lots of students from minority ethnic groups who live in remote areas in all over Indonesia had to swarm over to the island of Java to obtain better quality of education. Nonetheless, the students from minority ethnic groups were targeting to enrol or to study at either primary schools or at higher degrees in various majors to attain better educational values. One of the targets is at Malang, East Java. Malang that located in East Java; each year reportedly by several local newspapers had to embrace at least 22000 freshmen from various areas, including the remote areas in several provinces, who enrol to some colleges at Malang (Safitri, 2018).

In spite of the facts that have been mentioned before, the huge numbers of students that enrolled at the universities all over Java did not mean that each one of those students guaranteed to posses adequate skills to strive in new and well-equipped academic environment. As a result, many of the students from minority ethnic groups were having difficulties to compete and to adapt with their fellow students from different regions, especially from the students from the mainland of Java. There are various private and state universities in Malang that become the favourite destinations of students from various minority ethnic groups, therefore it can be inferred that some of the college students either at private or state universities in Malang originally derived from eastern Indonesian descents; Papuans, Moluccas, East and West Timor, Celebes, and etc.

One of the issues here was the students from minority ethnic groups were having difficulties in one the English language skills; 
writing. Specifically, it reflected on their vocabulary proficiency level in some writing classes. Therefore, the researcher perceived that the difficulties faced by students from minority ethnic groups must be discovered and immediately addressed to ensure adequate vocabulary proficiency in writing of the university students, notably the students from minority ethnic groups.

This research attempted to determine the issues faced by students of minority ethnic groups based on the relation of students' ethnicity, educational support and social aspects. Unlike the previous study by Ghaffarzadeh (2016) that aimed to discover the comparative study of discrimination in education in regards to social class and financial status.

As British writers, Cyril Connolly said; a great writer creates a world of his own and his readers are proud to live in it. A lesser writer may entice them in for a moment, but soon he will watch them filling out. In other words, a great nation could be measured by the resounding feat of their writing. Specifically, the writings produce by all of their proud their citizens; both majority and minority ethnic groups alike. The researcher, therefore, inquired these set of problems, about what are the issues related to vocabulary proficiency found in writing of students from minority ethnic groups, and how students of minority ethnic groups enhance their vocabulary proficiency in writing skills.

\section{Method}

This research utilises qualitative approach with anthropological approach; writing samples, questionnaire and interview sessions analysed using the Thick Description. These combined methods were utilised to discover the notion of the issues faced by the students from minority ethnic groups, and how the students from minority ethnic groups overcome that issues. After thorough analyses of students' writing samples using Voyant Tools, questionnaires and interview session, the researcher employed Thick Description to constitute an analysis regarding the results taken from combing the Voyant Tools, questionnaires and interview session regarding the students from minority ethnic groups well being, notably about their vocabulary proficiency in writing.

The participants were 16 English Education Department students who originally come from both minorities and majority ethnic groups were selected to be the participants of the research. They were chosen based on the preliminary research regarding the origin of their racial origins. Eight students who come from Javanese ethnic groups were selected as part of majority participants; on the other hand another eight students who come from Eastern Indonesian origins, Papuans, Moluccas, East and West Timor, and Celebes, were selected as part of minority participants.

Next, the instruments of this research were (1) Voyant Tools, (2) questionnaire, and (3) interviews. The combination of the result of writing samples in Voyant Tools, questionnaires, and interviews were performed to extract information about students' perception regarding students from minority ethnic groups' well-being in educational aspects. In addition, semi structured interview guide was manufactured according to Alterator and Deed (2013) work to discover the issue of students from minority ethnic groups well-being in educational context. Lastly, the data taken from both of the aforementioned instruments, Voyant Tools, questionnaire and interviews, were being taken into account in order to be analysed with Thick Description.

To discover the set of values within society represented at the aforementioned instruments, the researcher employed Thick Description to underline the importance of culture as part of human's society. Because human's societies consist of set of values that originated from human's interaction that could be understood by revealing the inferred meaning hidden within the society. As Geertz (1973) explained, culture is public because meaning is. Then, culture could be 
inferred to possess plenty set of meaning or justifying facts that could be uncovered or discovered by having deep and thorough analysis.

In order to be able to collect the data, the researcher employed the following steps:

1. Determining potential participants based on their racial origin and request of grant consent regarding their availability to get involved in the research.

2. Taking their writing samples to be analysed using Voyant Tools.

3. Delivering the questionnaire and performing interviews with the selected students from minority ethnic groups.

4. Performing necessary interviews to selected participants to gather more details regarding the selected issue.

5. Recording the content and providing the transcription of the content to validate and justify the information.

For the data analysis, the researcher employs context analysis of the context to analyse the data and discover the pivotal notions of the data classified according to the research problems. In order to complete the analysis, the following procedures are required: (1) classifying and selecting the necessary documents, (2) analysing the documents basing on the research problems, (3) analysing the results of the Voyant Tools, questionnaires and interviews, (4) triangulating and analysing the result with Thick Description, and (5) drawing the discussion and the conclusion.

\section{Result and Discussions}

By comparing the results using from both parties either from the students from majority and minority ethnic groups, the researcher discovered that the texts written by either of those respective ethnic groups were having slight differences. The researcher measured the results by using Voyant Tools; hence the following tables are the result from both parties. The result were measured based on vocabulary density and average words per sentence of each parties (see Table 1 and Table 2).

From both of the tables, either from the Minority Ethnic groups and Majority Ethnic groups, the researcher focused on the vocabulary density and the average words per sentence from students from both ethnic groups. Therefore, according to the tables above, the average score of the vocabulary density of the students from minority ethnic groups were slightly better compare to the students from majority ethnic groups. On the other hand, the average words per sentence of the majority ethnic groups were also slightly better compare to the students from minority ethnic groups. The researcher also discovered that actually each of the students from minority ethnic groups obtained better score at their vocabulary density compare to the students from majority ethnic groups. On the opposite, each of the students from minority ethnic groups obtained less good score at their average per sentence compare to their counterparts, the students from majority ethnic groups.

Afterwards, the researcher selected some of the students from minority ethnic groups based on the responses in their questionnaires containing their writing that analysed using Voyant Tools. The researcher chose these two students from minority ethnic groups because they earned highest score in their vocabulary density.

\subsection{The issues related to vocabulary proficiency of the minority ethnic groups' students}

The researcher here emphasised on the issues related to the vocabulary proficiency of the students from minority ethnic groups. The researcher gathered the data from the questionnaires distributed only to the students from minority ethnic groups, and the result of the interview session of the selected two students from minority ethnic groups.

Based on the questionnaires and the interview sessions, the researcher was able to infer that the students from minority ethnic groups were facing lots of obstacles to enhance their language proficiency, in this 
context the researcher was emphasising on the issue of vocabulary proficiency in writing.

Some of the obstacles that had been able to be discovered by the researcher were divided into two main obstacles; technical issues and social issues. First of all, the technical issues that had been able to be discovered were about the educational infrastructures in the ethnicity origins of the students from minority ethnic groups.

Table 1. Minority Ethnic Group

\begin{tabular}{ccccc}
\hline No & Name & Ethnicity & Vocabulary Density & Average Words per Sentence \\
\hline 1 & Student 1 & Ambon & 0.631 & 12.3 \\
\hline 2 & Student 2 & Alor & 0.917 & 12 \\
\hline 3 & Student 3 & Bugis & 0.743 & 17.5 \\
\hline 4 & Student 4 & Subaim, Maluku utara & 0.862 & 29 \\
\hline 5 & Student 5 & Buton & 0.7 & 13.3 \\
\hline 6 & Student 6 & Kei & 0.92 & 12.5 \\
\hline 7 & Student 7 & Taam & 0.658 & 9.5 \\
\hline 8 & Student 8 & Arifuru, Bugis & 0.718 & 19.5 \\
\hline & & Average Score & 0.768625 & 15.7 \\
\hline
\end{tabular}

Table 2. Majority Ethnic Group

\begin{tabular}{ccccc}
\hline No & Name & Ethnicity & Vocabulary Density & Average Words per Sentence \\
\hline 1 & Student 1 & Javanese & 0.577 & 23.4 \\
\hline 2 & Student 2 & Javanese & 0.582 & 22.5 \\
\hline 3 & Student 3 & Javanese & 0.62 & 16.1 \\
\hline 4 & Student 4 & Javanese & 0.559 & 20.8 \\
\hline 5 & Student 5 & Javanese & 0.454 & 24.6 \\
\hline 6 & Student 6 & Javanese & 0.444 & 18.9 \\
\hline 7 & Student 7 & Javanese & 0.417 & 18.5 \\
\hline 8 & Student 8 & Javanese & 0.456 & 20.475 \\
\hline & & Average Score & 0.513625 & 18 \\
\hline
\end{tabular}

The educational infrastructure such as textbooks, either academic or non academics, deficiencies in school structures, and lack of attention from the local authority and central government seemed to be the main obstacles that hinder their study. Those issues, notably, occurred at their ethnicity origins, another issues came up when they were enrolling or attending the classes during their study at the university. During their study, the researcher discovered that actually they realised that so far they felt ignored by the government during their time at primary schools, and they received lack of attention from the department, and the university about their well-being during the study. In addition, basing on premiss above the researcher also discovered that the students from minority ethnic groups also had difficulties in the grammatical structure and the spelling. 
Secondly, the researcher also revealed that the students also experiencing other problems at the context of the social aspects. One of which was the verbal abuse or individual discrimination from the students from majority ethnic groups due the differences in their ethnicity and educational or language proficiency. The students from majority ethnic groups were showing some discrimination towards the one of the respondents, students from minority ethnic groups, due the negative stereotypes about minority ethnic groups that originated from East Indonesians. In addition, based on the result of the interview researcher discovered that the students from majority ethnic groups said that due their ethnicity that different from the majority, the students from minority ethnic groups or remote areas are most likely to fail and will not reach any success in any level.

\subsection{Efforts of the students of minority ethnic groups to enhance their vocabulary proficiency in writing skills}

In this section, aside from the aforementioned obstacles found, the researcher also focuses more on the efforts made by the students from minority ethnic groups to enhance their vocabulary proficiency in writing. To gather the data, the researcher utilised questionnaires towards students from minority ethnic groups, and selected two students from minority ethnic groups who earned highest score in both scoring criteria at Voyant Tools; vocabulary density and average words per sentence.

Despite the technical issues and social issues beforehand, the researcher here found out that the respondents from the students of minority ethnic groups were able to overcome the issues they have faced by employing methods that suit their environment best. The primary issues that they faced were due to lack of educational infrastructures; adequate textbooks, deficiencies in school structures, and lack of attention either from local authority and central government. Based on that premiss, the researcher inferred that the students from minority ethnic groups made some efforts that worked best to enhance their vocabulary proficiency according to the condition of their upbringing at their ethnicity origins. Because The researcher perceived that suppose the students possess sufficient proficiency in vocabulary they would be able to gradually increase their English proficiency. As Fakhruddin, Yuliasri, and Barati (2013) stated that having sufficient vocabulary will help the students to master English language, and at the same time their English skills will gradually increasing. Besides, by having sufficient amount of vocabulary will assist the students to improve their writing, and representing someone's capability of the language itself. As Kheryadi (2017, p. 381) explained,

"Not like other skills, writing needs students' creativity, imagination, and knowledge to arrange what their ideas in their minds will bear in written response. It is essentially a reflective activity that requires ample time to consider about a certain topic, to analyze and to classify any background knowledge."

However, the researcher was able to expose that there were several methods developed by the respondents in order to enhance their vocabulary proficiency. First, the students from minority ethnic groups were employing songs and its' lyrics to enhance their vocabulary proficiency. Based on that, the researcher interpreted that by employing the method that relying at their passive skill which is listening skill, the students from minority ethnic groups were able to enjoy listening to music while memorising the new vocabularies found at the song's lyrics. Second, the students from minority ethnic groups were reading stories from novel or short stories, or other textbooks available, and then they wrote down the vocabularies that had been discovered recently. According to that premiss, the students from minority ethnic groups attempted to enhance their vocabulary level by fully utilising another passive skill which 
is reading and combined it with active skill, which is writing.

Eventually, the researcher would like to elaborate about the state of educational quality of the students from minority ethnic groups and its' relation to their vocabulary proficiency in writing, notably for those who originally came from remote areas in east Indonesians; Sulawesi, Moluccas, East and West Timor, and Papuans.

First of all, the researcher discovered that actually students from minority ethnic groups, specifically those who originated from East Indonesians were facing lots of technical issues related to the upbringing of the educational state. The researcher inferred that the technical issues such as lack of educational infrastructure existed due to the inequality of education in remote areas compare to their counterparts at central area. Educational infrastructure according to Cohen and Bhatt (2012), could be well defined as, the elements of educational infrastructure include examinations, curricula or curriculum frameworks, teacher education, inspection systems or other means to observe and improve instruction, and a teaching force whose members succeeded in those curricula and exams as students.

Therefore, the researcher implied that the educational infrastructure in remote areas, notably where the minority ethnic groups in East Indonesian provinces, were still underdeveloped due the educational infrastructure that still underequipped and underfunded. By any means, any elements in educational infrastructures in remote areas were still far from complete, however, the curriculum in remote and central area were similar. As a result, the students from minority ethnic groups felt underappreciated, because they felt ignored and the current educational infrastructures did not suit their condition at remote areas, which resulted at their bad grades or even low-education rates or high rates of drop out. Therefore, for the sake of minority ethnic groups in remote areas in the near and foreseeable future, education as basic human rights must be improved to enhance students' well-being, hence improvement of educational situation will assist in enhancing minority ethnic groups' well being as well as reducing poverty, related-diseases, famine, which hopefully lead to the socio-economic growth (Ghaffarzadeh, 2016).

On the other hand, the students from majority ethnic groups, who lived at central areas, were given the same curriculum but with better equipped educational infrastructures. The researcher basing that premiss based on report by Non Governmental Organisation that concerned about education from United Kingdom, Send My Friend To School (2019, p. 11):

"Children and young people from ethnic minorities, indigenous groups and nomadic and pastoralist communities may experience fewer rights and therefore have difficulty in accessing education. When they do access education, however, they will often be taught in a language they don't understand, and a curriculum not sensitive to their local context and lifestyle, which exacerbates dropout rates and reinforces social exclusion."

Based on that premiss, it can be inferred that educational systems in Indonesia still inequitable for the students from minority ethnic groups who live in remote areas compare to the students from majority ethnic groups who live in municipality that relatively close to the central government or around central areas at Java Island. In other words, the students from majority ethnic groups, or those who live in Java Island would be getting better attention compare to those who live in remote areas. As briefly stated by Cohen and Bhatt (2012, p. 118):

"...,we argue that the key organizational features that have shaped the quality of teaching in all subjects, including literacy, are the lack of educational infrastructure, a decentralized governance system, and the organization of teaching as an occupation. Each of 
these features impedes efforts to improve literacy instruction, yet they are seldom the target of reforms."

As a result, the vocabulary proficiency of the students from minority ethnic groups was considered less good than the students from majority ethnic groups. Lack of proficiency of vocabulary eventually led to students' incapability to understand or to follow the lesson. Ilmi and Fitriati (2020) discussed that; lack of vocabulary knowledge will lead students to the failure of understanding the texts and instructions. In other words, educational reforms for students from minority ethnic groups were required in order to ensure equal and quality education to all citizens. One of which is to be able to provide adequate support for students who wish to improve their vocabulary.

However, in order to achieve adequate educational the researcher also perceived that actually the students from minority ethnic groups in East Indonesian provinces not only required educational reforms, but also extra attention and shown extra regards for the implementation of educational reforms to ensure quality education for minority ethnic groups in remote areas, especially at east Indonesian provinces. This notion briefly supported by Datu (2018, p. 203) as follow,

"School, educational, and counseling psychologists can develop and implement psychoeducational interventions that will primarily focus on enhancing the students' sense of appreciation to other students from various cultural or racial backgrounds. Mental health professionals in the educational settings are also recommended to create individual and group counseling interventions which can improve the socio-emotional skills (e.g., emotional intelligence and perseverance) of students who are vulnerable to experience everyday discrimination."

This premiss also explained by Cohen and Bhatt (2012) that, the mere existence of infrastructure does not ensure excellent or effective education; that depends on how well the infrastructure is designed and used.

Besides the aforementioned technical issues that hindered the students' achievement in vocabulary proficiency in writing, the researcher also would like to elaborate more about social issues. The social issue that the researcher interpreted thoroughly was the existence of verbal abuse or discrimination that had been directed to the students from minority ethnic groups. Therefore, encountering the subtle and daily basis discrimination potentially serves to negatively affecting the students' academic performance, as well as their emotional state which reflected to their well-being and academic outcomes (Datu, 2018). In this context, the researcher regarded that some of majority ethnic groups performed individual discrimination that had been carried out towards students from minority ethnic groups due to the distinctive traits between their ethnicity. As Ferris and Stein (2010) elaborated about individual discrimination as follow, individual discrimination occurs when one person treats others unfairly because of their race or ethnicity. A racist teacher might discriminate against a Hispanic student by assigning him a lower grade than he deserves.

Based on premiss above and the interview session towards selected students from minority ethnic groups, the researcher discovered that individual discrimination towards students from minority ethnic groups emerged due the negative stereotypes labelled towards minority ethnic groups from east Indonesian areas, which led the majority ethnic groups to perceive that the students from minority ethnic groups from remote areas in East Indonesians would not reach any success and likely to fail. Basing on that premiss, the researcher inferred that the individual discrimination addressed towards students from minority ethnic groups from east Indonesian existed due the embedded negative stereotypes such as lazy, illiterate, uneducated, drunkard, and the dark complexion of the ethnicities from East 
Indonesian resembled closely to the imagery of evil doers or even worst, savagery. As clearly stated by Tindall and Shi (2013, p. 118) below,

"The English in the seventeenth century associated the color black with darkness and evil; they stamped the different appearance, behavior, and customs of Africans as "savagery." Most of the selfserving qualities that colonial Virginians imputed to blacks to justify slavery were the same qualities that the English assigned to their own poor to explain their lowly status: their alleged bent for laziness, treachery, and stupidity, among other shortcomings."

Consequently, the individual discrimination performed by the majority ethnic groups was considered as a tool to show their disapproval towards minority ethnic groups, and it also could be inferred that some of the students from majority ethnic groups were feeling far superior compare to the students from minority ethnic groups. Therefore, the researcher perceived that in order to maintain the superiority, the majority ethnic groups' utilised individual discrimination towards the inferior groups, or towards the students from minority ethnic groups. The researcher also regarded that the utilisation of individual discrimination was one of the means performed by majority ethnic groups to assert or maintain their dominance towards the minority ethnic groups. As Wiraatmaja (2019, p. 78) stated below,

“...the majority or superior group will most likely try to assert or maintain their dominance over less superior group by utilizing the idea of racism as a method to assert or to maintain their dominance or superiority over the inferior or minority group."

Therefore, based on that premiss the researcher argued that the majority argued had to utilise individual discrimination because their privilege as the superior group was being confronted, hence some of the majority ethnic groups had to perform individual discrimination in order to assert or maintain their privilege as superior compare to the minority ethnic groups from east Indonesians as the inferior groups. As Ferris and Stein (2010) explained about as follow, "an ideology or set of beliefs about the superiority of one racial or ethnic group over another provides this support; it is used to justify social arrangements between the dominant and minority groups". In other words, the researcher regarded that individual discrimination emerged because some of the majority ethnic groups believed in social arrangements, in which the majority ethnic groups as the superior, and the minority ethnic groups as the inferior.

Specifically, the researcher also valued the response of the students from minority ethnic groups when facing discrimination towards them. Nevertheless, the researcher argued that despite the existence of individual discrimination during their study. In addition, the students from minority ethnic groups were striving to prove that the stereotypes and the discrimination towards them were all wrong, and the students from minority ethnic groups bested the students from minority ethnic groups at the context of Vocabulary Density in Voyant Tools. Moreover, despite the aforementioned obstacles, the students from minority ethnic groups were able to develop methods that suit them best in order to enhance their vocabulary proficiency in writing.

As Astika (2016) stated that, proper and sufficient amount of vocabulary can affecting students' mastery of language skills, either receptive skill; listening and reading, and the productive skill; speaking and writing. Due to that reasons, students' writing should get better and proper attention during the teaching and learning process to constitute the learners or students' capability in dealing with authentic communicative situation (Fadilllah, 2019). Therefore, by having adequate vocabulary level and good mastery in writing, the students' from minority ethnic 
groups would be able to gradually change the negative stereotypes towards them. Because by having sufficient vocabulary that considered essential in learning English, the learners who do not posses adequate vocabulary will facing difficulty in interacting and understanding others (Putri \& Wahyuni, 2019).

The researcher basing this idea based on the result found at Voyant Tools, which can be perceived in the tables above that comparing both ethnic groups; minority and majority ethnic groups. The average score of the vocabulary density of the students from minority ethnic groups were 0.768625 , which was better compare to the students from majority ethnic groups that only earned 0.513625 (see Table 1 and Table 2)

Despite the premiss above, although the students from minority ethnic groups able to develop methods that suit them best. The researcher also emphasised that the efforts made the students from minority ethnic groups were not able to assist them in the context of grammar and spelling, as clearly seen at their writing samples. In which, the researcher regarded that extra care and attention were needed to be given to these students to improve their well-being in the context of grammatical and spelling errors found at their writing samples.

\section{Conclusion}

Education, in any level, is the spearhead to reach success, as a tool to break any stereotypes and discrimination based on one's ethnicity background, biological makeups, and any social backgrounds. However, education in some nations still becoming secondary objectives and mostly underfunded, and it resulted in the underequipped quality of educational infrastructures of students from minority ethnic groups, especially those from remote areas that being left behind by their own countrymen, the majority ethnic groups who live in central area or municipality that close to the central government. It also applied to the vocabulary proficiency of students from minority ethnic groups that were considered as being less-developed compare to their fellow students from majority ethnic groups. Besides underequipped educational infrastructure, ironically, the researcher also discovered the harsh existence of the socalled stereotypes towards students from minority ethnic groups that resulted to the notion of individual discriminations performed by some of the students from majority ethnic group. Consequently, the individual discrimination performed by the majority one's also badly affecting the educational well-being of the students' from minority ethnic groups, one of which was their vocabulary proficiency.

Nevertheless, aside from underequipped educational infrastructure and individual discriminations, the students from minority ethnic groups still strive to reach success. One of which was shown through their feat at the context of vocabulary proficiency. Although the students from minority ethnic groups were facing educational deficiencies at their ethnicity-origin at remote areas, they made some efforts that suit them best, using song's lyrics and reading some prosaic and academic books which helped them a lot in improving their vocabulary proficiency, see Table 1 and Table 2. Although, the researcher discovered that these methods were not able to improve their well-being in the context grammatical and spelling prowess.

Eventually, the researcher aimed to reprimand the central government that the students from minority ethnic groups at remote areas were supposed to be given curriculum that suited best to their upbringing, that relatively under-equipped compare to the students who live at central areas or at island of Java. As for the university, the students from minority ethnic groups were needed to be given extra attention before start studying at the university, so they will not be treated unequally or being discriminated by the students from majority ethnic groups due to their lack of proficiency in vocabulary in writing or in any other aspects. 


\section{References}

Alterator, S., \& Deed, C. (2013). Teacher adaptation to open learning spaces. Issues in Educational Research, 23(3), 315-330. Retrieved from http://www.iier.org.au.

Astika, G. (2016). Profiling Vocabulary of English Textbooks for Indonesian Junior High SchoolsUsing Vocabulary Profiler: A Fast Tract to Improve Students' Vocabulary Knowledge. IJOL-TL (Indonesian Journal of Language Teaching and Linguistics), 1(3), 203-218. doi:https://doi.org/10.30957/ijoltl.v1i $\underline{3.185}$

Cities, R. (2018). School Infrastructure Resilience (Report) Retrieved from http://100resilientcities.org/wpcontent/uploads/2018/08/100-

Resilient-Cities-SchoolInfrastructure-Resilience-CoLabWorkshop-Report.pdf.

Cohen, D. K., \& Bhatt, M. P. (2012). The importance of infrastructure development to high-quality literacy instruction. The Future of Children, 22(2),

117-138. doi:https://doi.org/10.1353/foc.2012. $\underline{0012}$

Datu, J. A. D. (2018). Everyday discrimination, negative emotions, and academic achievement in Filipino secondary school students: Cross-sectional and cross-lagged panel investigations. Journal of School Psychology, 68, 195-205. doi:https://doi.org/10.1016/j.jsp.2018 .04 .001

Fadilllah, R. (2019). Students' Perception on the use of Mind Mapping Application Software in learning writing. CELTIC: A Journal of Culture, English Language Teaching, Literature, and Linguistics, 6(2), 5864.
doi:http://dx.doi.org/10.22219/CELT ICUMM.Vol6.No1.58-64

Fakhruddin, A., Yuliasri, A., \& Barati, D. A. L. (2013). The Effect of Jigsaw and Pair Switch Partner Present of The High and Low Motivated Students' Vocabulary Mastery. English Education Journal of UNNES, 3(2), 52-59. Retrieved from https://journal.unnes.ac.id/sju/index. php/eej/article/view/2707

Ferris, K., \& Stein, J. (2010). The Real World 2nd Edition, an introduction to Sociology. New York: W.W. Norton \& Company

Geertz, C. (1973). The Interpretation of Culture. New York: Basic Books.

Ghaffarzadeh, M. (2016). A Comparative Study of Discrimination in Education: The Learning Environment and Behaviours of Students and Teachers in Iran. The IAFOR Journal of Education, 4(2), 34-46.

doi:https://doi.org/10.22492/ije.4.2.0 $\underline{2}$

Ilmi, I. K., \& Fitriati, S. W. (2020). Teachers' Perceptions, Plans, and their Practices on Teaching Vocabulary in Context at SMPN 1 Parakan, Temanggung. English Education Journal of UNNES, 10(2), 154-163. doi:https://doi.org/10.15294/eej.v10i 1.34214

Kheryadi, K. (2017). Improving Students' Writing Narrative Through Writing Games for Accelerations Class. EduLite Journal of English Education, Literature and Culture, 2(2), 389-404. doi:http://dx.doi.org/10.30659/e.2.2. $\underline{377-388}$

Putri, M. Z., \& Wahyuni, E. (2019). Vocabulary Learning Strategy Employed by High Achiever 
University Students at Malang. CELTIC: A Journal of Culture, English Language Teaching, Literature, and Linguistics, 6(1), 7889.

doi:http://dx.doi.org/10.22219/CELT ICUMM.Vol6.No1.78-89

Safitri, A. E. (2018). Puluhan Ribu Mahasiswa Baru Siap Kepung Kota Malang. Kumparan. Retrieved from https://kumparan.com/malangtoday/ puluhan-ribu-mahasiswa-baru-siapkepung-kota-malang27431110790544906

School, S. M. F. t. (2019). Unlock Education for Everyone: delivering the pledge to leave no one behind in education (Report) Retrieved from https://sendmyfriend.org/wp/wpcontent/uploads/2019/02/2019report.pdf.

Tindall, G. B., \& Shi, D. E. (2013). America: A Narrative History (Vol. 1). New York: WW Norton and Company.

Wiraatmaja, T. (2019). The Relation Of Minority Group's Sport Attainment To Counter Racism: AfricanAmerican In The Movie 42. EduLite Journal of English Education, Literature and Culture, 4(1), 76-86. doi:http://dx.doi.org/10.30659/e.4.1. $\underline{76-86}$ 